\title{
Uteroplacental vascular development and placental function: an update
}

\author{
LAWRENCE P. REYNOLDS*, PAWEL P. BOROWICZ, JOEL S. CATON, KIMBERLY A. VONNAHME, JUSTIN S. \\ LUTHER, DAVID S. BUCHANAN, SHIREEN A. HAFEZ, ANNA T. GRAZUL-BILSKA and DALE A. REDMER \\ Center for Nutrition and Pregnancy, and Department of Animal Sciences, North Dakota State University,
} Fargo, ND, USA

\begin{abstract}
The importance of the placenta and its vascular development to fetal growth and development has been appreciated since ancient times. Based on numerous studies in humans and animal model organisms in the last 2-3 decades, normal placental angiogenesis is critically important to ensure adequate blood flow to the placenta and therefore to provide the substrates that support normal fetal growth. Placental angiogenesis is abnormal at term in compromised pregnancies (those in which fetal growth is altered), including those resulting from maternal nutritional or environmental stress, maternal age, increased numbers of fetuses, maternal or fetal genotype, or the use of assisted reproductive technologies (e.g., cloning by somatic cell nuclear transfer). We and others have recently shown that these defects in placental vascular development occur quite early in pregnancy and may therefore presage compromised fetal growth and development. The challenges will be to find biomarkers of abnormal placental angiogenesis and to develop therapeutic strategies to "rescue" placental vascular development and thus fetal growth in compromised pregnancies. Animal models will be essential in meeting these challenges.
\end{abstract}

KEY WORDS: placenta, angiogenesis, pregnancy, fetal growth, regulation, therapeutic

The [umbilical] vessels join on the uterus

like the roots of plants and through them

the embryo receives its nourishment.

Aristotle. On the Generation of Animals (ca. 340 B.C.)

\section{Introduction}

As pointed out in this issue (Longo and Reynolds, 2010), the importance of the placenta and its vascular development to fetal growth and development has been appreciated since ancient times, as the quotation from Aristotle, above, makes abundantly clear. More recently, Longo (1972) put a modern spin on this concept when he stated, "The fetal 'lifeline' thus includes an adequate maternal placental circulation and supply of blood nutrients, a placenta that transports and metabolizes various substances properly and a functional fetal placental circulation."

Perhaps based in part on the study of bird embryos (the Egyptians and probably also the Chinese developed a system for the artificial incubation of bird eggs as early as 3,000 B.C.E.; Needham, 1934), the ancient investigators recognized the correct function of the placenta and umbilical cord. These studies also led the ancient investigators to recognize that early development of the chick and mammals had many similarities. This revelation led to the use of the developing chick as the most important model organism for embryological research in vertebrates from that time forward, and established the importance of animal models in obstetric research. Thus, animal models have been central to the study of the placenta and the placental circulation since the earliest times, and much of our knowledge of placental vascular development continues to be derived from comparative studies in animals (Kaufmann et al., 2004; Reynolds et al., 2005b; Longo and Reynolds, 2010). Fortunately, the power of the comparative approach in solving complex biological problems is widely recognized and has been not only widely applied but highly successful.

Based on numerous studies in humans and animal model

Abbreviations used in this paper: ANGPT, angiopoietin; eNOS, endothelial nitric oxide synthase; FGF, fibroblast growth factor; NO, nitric oxide; VEGF, vascular endothelial growth factor.

\footnotetext{
*Address correspondence to: Dr. Lawrence P. Reynolds. Center for Nutrition and Pregnancy, and Department of Animal Sciences, North Dakota State University, Hultz Hall, Fargo, ND 58108-6050, USA. Fax: +1-701-231-7590. e-mail: Larry.Reynolds@ndsu.edu
} 


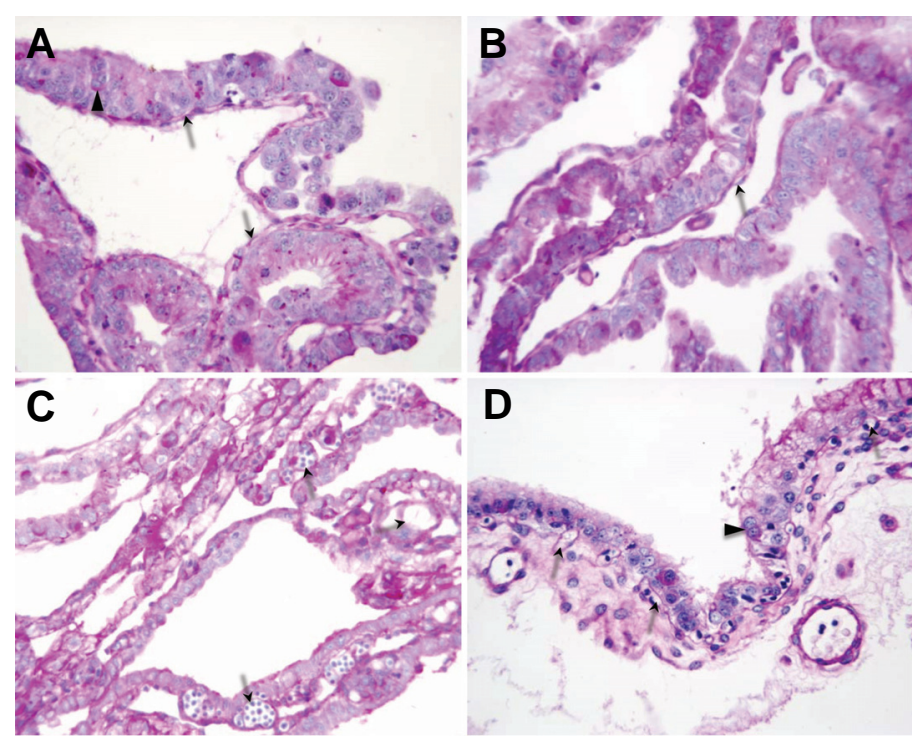

Fig. 1. Chorioallantois (fetal placenta) on day 24 of pregnancy from (A) IVF, (B,C) parthenogenetic, and (D) normal sheep embryos. (Arrows indicate placental capillaries; arrowheads indicate binucleate cells in $(A, D)$; Borowicz, Grazul-Bilska, Ptak, Loi, Palmieri, Della Salda, and Reynolds, unpublished)

organisms, adequate blood flow to the placenta is critical for normal fetal growth. It is therefore not surprising that conditions that affect fetal growth, such as maternal and fetal genotype, increased numbers of fetuses, maternal nutrient excess or deprivation, or environmental stress, have similar effects on placental growth and are associated with reduced rates of fetal oxygen and nutrient uptakes, as well as reduced placental angiogenesis and blood flow (Vonnahme et al., 2001, 2002; Anthony et al., 2003; Wallace et al., 2005; Reynolds et al., 2006). Similarly, in highly compromised pregnancies established using assisted reproductive technologies, such as somatic cell nuclear transfer, placental angiogenesis is also highly compromised at term (Palmieri et al., 2007), and this defect in placental vascular development seems to occur quite early in pregnancy (Borowicz et al., unpublished, Fig. 1).

The critical role of the placental blood supply in humans is confirmed by the observation that intrauterine growth restriction in third-trimester pregnancies is characterized by impaired uterine (maternal placental) and umbilical (fetal placental) blood flows, leading to reduced fetal nutrient uptakes as well as fetal hypoxia, hypoglycemia and asymmetric organ growth (Pardi et al., 1993; Marconi et al., 1996; Ferrazi et al., 2000; Konje et al., 2003). In addition, increased uterine vascular resistance and reduced uterine blood flow during early pregnancy can be used as predictors of high-risk pregnancies and are associated with fetal growth retardation (Trudinger et al., 1985; North et al., 1994).

More than a decade ago, we presented a review in which we discussed the current evidence for the importance of placental vascular development to placental function and fetal/neonatal growth and development (Reynolds and Redmer, 1995). In the present review, we will provide an 'update' of what we have learned in the intervening decade concerning placental blood flow and vascular development.

\section{An update}

Throughout this article, we will emphasize data in ruminants, for which there are numerous well established models of compromised pregnancy, but we also will discuss the relevance to other species, including humans, where applicable. Ruminant models are relatively unique in that, macroscopically, the ruminant placenta comprises 60 to 100 discreet structures, or units, known as placentomes (Ramsey, 1982; Mossman, 1987). Each of these placentomes consists of maternal caruncular and fetal cotyledonary portions, which interdigitate and thus are in close apposition, thereby facilitating transplacental exchange of nutrients, respiratory gases, and wastes (Fig. 2; Ramsey, 1982). In mammals with epitheliochorial placentation (moles, manatees, whales, horses, pigs, cattle, sheep, and a few prosimians), the chorioallantois (the 'definitive' placenta of eutherian mammals) is minimally invasive, and thus the uterine epithelium remains intact during pregnancy (Ramsey, 1982; Mossman, 1987; Wooding and Flint, 1994). ${ }^{1}$ Because of this, the ruminant placenta is an ideal model for studying placental development because the maternal and fetal portions of the placenta remain closely associated but intact, and thus one can evaluate each tissue separately (Ramsey, 1982; Reynolds \& Redmer, 1995; Reynolds et al., 2005 a,b). In addition, as described later, although the epitheliochorial placenta of ruminants and other ungulates is quite different anatomically from the hemochorial placenta of most mammals, functionally they appear to operate quite similarly.

\section{Further evidence for the importance of placental angio- genesis and blood flow}

As we indicated in our 1995 review, based on the Fick principle, placental transport capacity, also termed placental uptake, can be calculated as:

Uptake $=$ blood flow $\times[A-V]$,

where $[A-V]$ represents the arteriovenous concentration difference (represented as $[v-a]$ for the umbilical vein minus umbilical arterial, or fetal, uptake; Reynolds and Redmer, 1995). Thus, transplacental exchange could increase by increasing the rate of extraction (the $\mathrm{A}-\mathrm{V}$ concentration difference) or by increasing the rate of blood flow, or both.

Based on numerous studies, it seems that increased blood flow is critical to increased transplacental exchange throughout gestation (Meschia, 1983; Reynolds et al., 1986, 2006; Metcalfe et al., 1988; Reynolds and Redmer, 1995). For example, in cattle from mid to late gestation, oxygen extraction by the gravid uterus increases only 0.4 -fold, whereas uterine blood flow increases approximately 4.5 -fold (Reynolds et al., 1986). Thus, increased uterine blood flow accounts for most of the 5 - to 6 -fold increase in

\footnotetext{
${ }^{1}$ Note that the sheep has now been reclassified as a subset of epitheliochorial, termed 'synedesmochorial' because the maternal epithelium is 'invaded' and modified by the trophoblast to form a syncitium. Additionally, although there are similarities in placental function between the epitheliochorial and hemochorial (as in rodents, insectivores, and anthropoids) types, there also are some functional differences such as transport of immunoglobulins across the hemochorial but not the epitheliochorial chorioallantoic placenta (Wooding and Flint, 1994).
} 


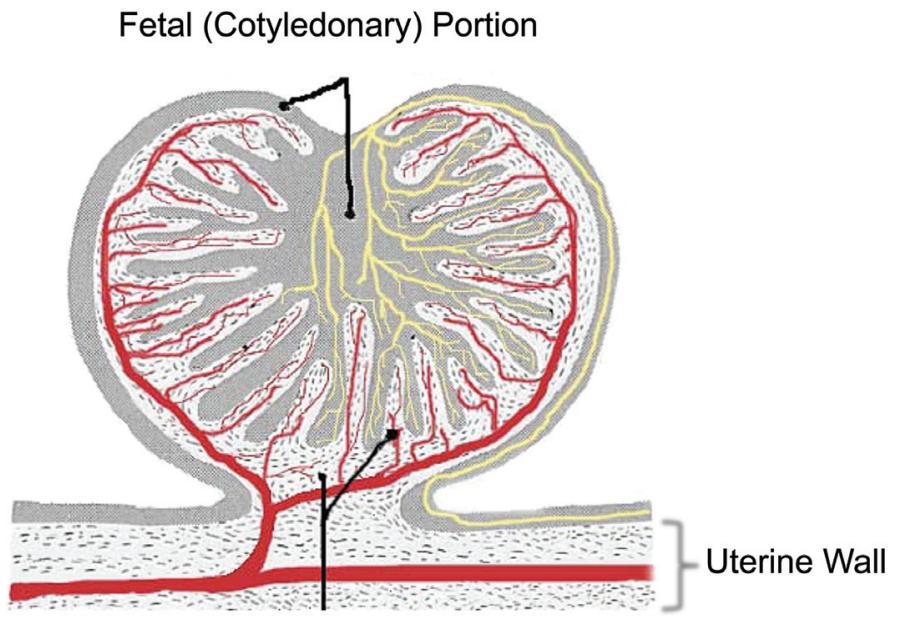

Maternal (Caruncular) Portion

Fig. 2. Schematic representation of the sheep placentome. Taken from Reynolds et al., 2005b.

total gravid uterine oxygen uptake. The 16-fold increase in oxygen uptake of the bovine fetus from mid to late gestation also can be accounted for primarily by the increased rate of umbilical blood flow (Reynolds et al., 1986). Similarly in sheep, gravid uterine oxygen extraction increases approximately 0.4 -fold from mid to late gestation, whereas uterine blood flow increases approximately 3-fold (Meschia, 1983). Moreover, the large increases in gravid uterine and fetal uptakes of glucose, lactate, and amino acid nitrogen from mid to late gestation in cattle seem to depend primarily on large increases in uterine and umbilical blood flows because the A-V concentration differences for these nutrients remain relatively constant (Reynolds et al., 1986; Reynolds and Redmer, 1995).

Thus, adequate blood flow to the placenta is critical for normal fetal growth. This does not, however, minimize the importance of concomitant increases in the abundance of specific transporters and an increase in the maternal to fetal concentration gradient also seem to be important components of increased transplacental exchange, at least for those substances that are diffusion limited (or transporter dependent), such as glucose and amino acids (Bell et al., 1999). Nevertheless, gravid uterine and umbilical glucose uptakes, which provide for about $60 \%$ of fetal metabolic needs (Reynolds et al., 1986; Bell et al., 1999), are reduced approximately in proportion to the reduction in placental mass and blood flows in pregnancies compromised nutritionally or by environmental heat stress (Reynolds et al., 1985, 2006).

Based on the concept that chronic increases in blood flow to any growing tissue depend on vascular growth, or angiogenesis, Meschia (1983) reasoned "the large increase of blood flow to the uterus during pregnancy ... results primarily from the formation and growth of the placental vascular bed." Numerous studies have subsequently confirmed that angiogenesis is indeed a major component of the increase in placental blood flow throughout gestation, and establishment of functional fetal and placental vascular beds is one of the earliest events during embryonic/ placental development (Reynolds and Redmer, 1992, 1995; Magness, 1998; Charnock-Jones et al., 2004; Kaufmann et al., 2004; Mayhew et al., 2004; Reynolds et al., 2005a,b; Borowicz et al., 2007). In fact, not only does the sustained increase in gravid uterine and umbilical blood flows depend on development of the placental vascular beds, but placental growth itself depends on placental angiogenesis because tissue growth of any magnitude normally cannot occur in the absence of vascular growth (Bassingthwaighte and Goresky, 1984; Hudlicka, 1984). This dependence on vascular development results from the high metabolic demands associated with tissue growth and the limited ability of respiratory gases, nutrients, and metabolic wastes to diffuse through the extracellular compartment (Bassingthwaighte and Goresky, 1984; Adair et al., 1990). Thus, growth and development of the vascular beds are critical components of tissue growth and function, including that of the uteroplacenta, and as mentioned, the importance of vascular development to placental function has long been recognized. However, research on placental vascular growth has comprised primarily descriptive histological studies, whereas only a handful of quantitative studies of placental angiogenesis have been reported (Kaufmann et al., 2004; Mayhew et al., 2004; Reynolds et al., 2005b).

The evaluation of placental angiogenesis has utilized primarily 2 methodologies: (1) classical histological methods involving embedding, sectioning, and staining, followed by stereological analysis (more recently, using confocal microscropy and computerized image analysis) of the microcirculation, and sometimes involving perfusion fixation (Borowicz et al., 2007; Vonnahme et al., 2007); and (2) vascular casting procedures utilizing perfusion with a casting medium such as Batson's No. 17, followed by digestion of the tissue and scanning electron microscopic evaluation of the remaining microvascular cast (Hafez et al., 2007).

To evaluate uteroplacental angiogenesis during early preg-
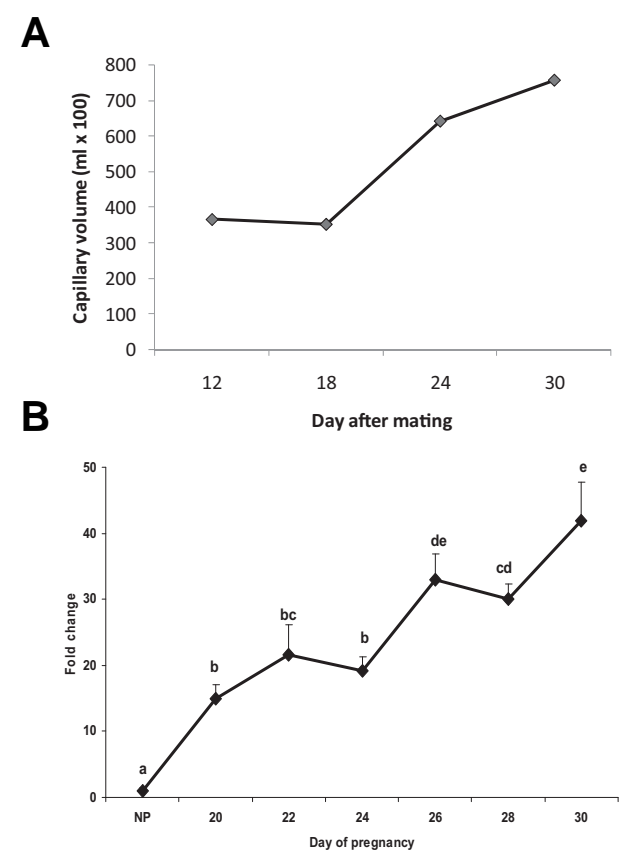

Fig. 3. Maternal placental angiogenesis from days 12-30 of pregnancy in sheep (equivalent to days 22 to 54 in humans). (A) Total capillary vascular volume and (B) capillary labeling index (relative rate of cell proliferation) of maternal placental tissues through day 30 of early pregnancy in sheep. 
nancy, we have used simple, classical histological methods, with immersion fixation followed by paraffin embedding and sectioning of the fixed tissues. We have been able to use these methods because the tissues are still relatively 'normal' and, thus, the vessels comprising the microcirculation (arterioles, capillary beds, and venules) are more easily identified than those during mid to late pregnancy, which we will discuss in the next paragraph. These methodologies have been described in detail by Reynolds and Redmer (1992). Although we have utilized several more specific methods to identify the microvessels in other tissues, such as immunohistochemistry for Factor VIII, smooth muscle cell alpha-actin, or histochemistry using specific lectins (Jablonkaworked as well for the fetal placenta. Thus, we have used primarily periodic acid-Schiff's reagent, which is a more general staining method for basement membranes, to identify the placental microcirculation (Hudlicka, 1984; Reynolds and Redmer, 1988; Reynolds and Redmer, 1992; Borowicz et al., 2007).

In contrast with those during early pregnancy, the microcirculatory beds of the uteroplacenta later in pregnancy are highly interdigitated, and the microvessels, especially those of the fetal cotyledons, or villi, are much more difficult to identify, both because some of the capillaries seem to be so immature that they do not readily stain using classical microvascular markers (Factor VIII, lectins, etc.) and also because they seem to collapse easily, probably because of the high water content of the placental tissues. Thus, to solve these problems, we have developed perfusion fixation techniques similar to those we have previously described (Jablonka-Shariff et al., 1996). These placental perfusion fixation methods that we have developed have been deShariff et al., 1993; Redmer et al., 2001), these methods have not

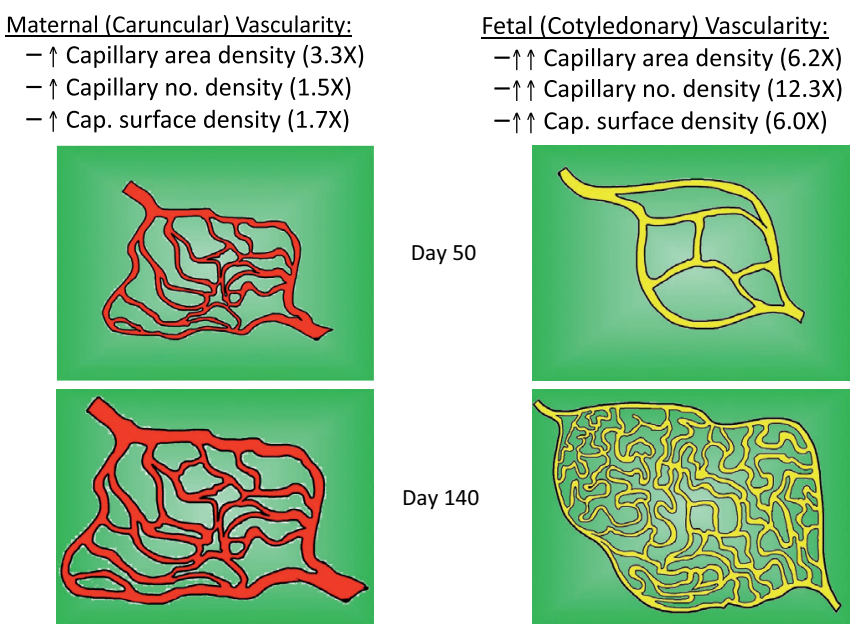

Fig. 5. Model of angiogenesis in the sheep placenta throughout the last two-thirds of gestation (taken from Borowicz et al., 2007).

scribed in detail by Borowicz et al. (2007) and Vonnahme et al. (2007).

Using these methods, we have shown that total capillary volume of the maternal placenta in sheep increases dramatically after day 18 of pregnancy, in conjunction with dramatic capillary growth (Fig. 3). This growth of the placental microvascular beds, including both the maternal and fetal placental tissues, continues throughout pregnancy (Fig. 4). These quantitative histological methods also have allowed us to develop a model of placental microvascular development (Fig. 5). In this model, the caruncular (maternal placental) capillary beds grow
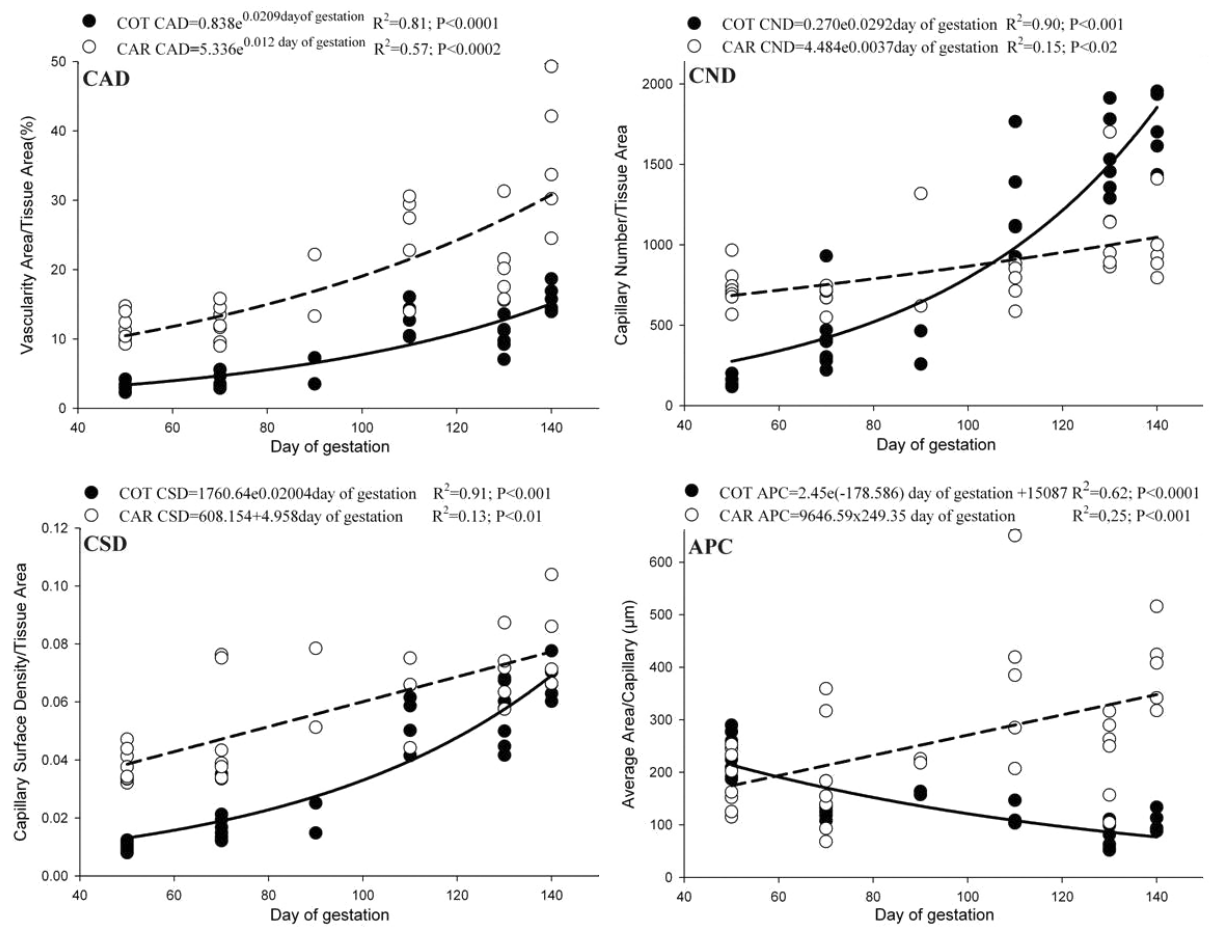

Fig. 4. Regressions of vascularity measures for caruncular (CAR, maternal) and cotyledonary (COT, fetal villus) placental tissues throughout the last two thirds of gestation in sheep (taken from Borowicz et al., 2007). primarily via an increase in capillary size (area per capillary), with only small increases in capillary number or surface densities, resulting in a modest, 3-fold increase in capillary area density. In contrast, the cotyledonary (fetal villous) capillary beds grow primarily by branching, resulting in a large, 12 -fold increase in capillary number density, accompanied by a decrease in capillary size. The relatively large, 6-fold increase in capillary area and surface densities of the fetal villi (Fig. 5) can be explained by this branching pattern of growth.

Our empirical model of angiogenesis in the caruncles and cotyledons is corroborated by studies of the physiological and anatomical constraints on morphology of vascular beds (Reynolds etal., 2005c). For example, according to "Murray's Law," the diameter (D) of a parent vessel is equal to the sum of the cube roots of the diameters of its branches; i.e., $\left(D_{\text {parent }}\right)^{1 / 3}=\left(D_{\text {branch } 1}\right)^{1 /}$ $3+\left(D_{\text {branch 2 }}\right)^{1 / 3}+\ldots+\left(D_{\text {branch n }}\right)^{1 / 3}$ (Murray, 1926; Hutchins et al., 1976; West et al., 1997). Assuming 2-fold branching (i.e., two branches per parent vessel, or a bifurcated system) and using Murray's law, we 
Caruncle - schematic showing actual size (left) and enlargement of area in box (right)

A
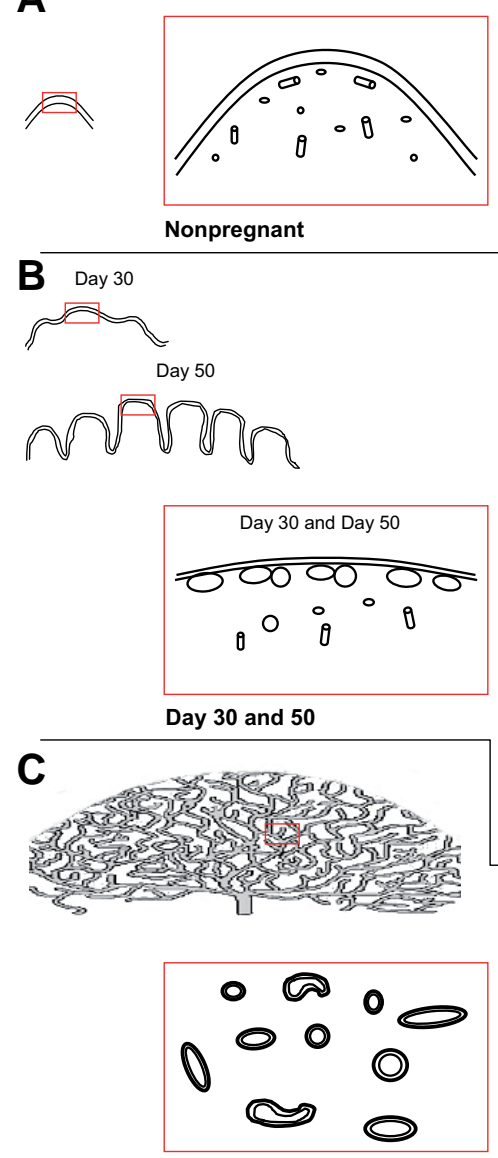

Day 130
Caruncle -

actual Histological Section
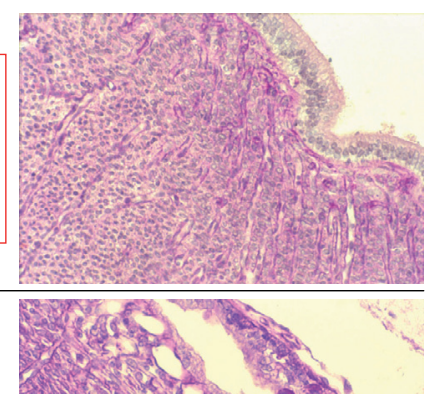

(about day 90 to 100 of gestation in sheep), the maternal caruncular tissue is composed primarily of these large 'capillaries,' many exhibiting diameters of $20 \mu \mathrm{m}$ or more (Reynolds et al., 2005c; Borowicz et al., 2007). In contrast, the diameter of the fetal capillaries decreases throughout gestation, resulting in an average capillary diameter of $4.5 \mu \mathrm{m}$ by the end of gestation (Reynolds et al., 2005c; Borowicz et al., 2007). In addition, our recent electron microscopic evaluation of vascular casts has confirmed this dramatic difference in microvascular architecture between the fetal and maternal placental tissues (Fig. 7).

The microvascular architecture of the maternal placental compartment is characterized by a preponderance of very large capillaries, which dictates a low-velocity, 'irrigation-flow' or slowly percolating type of system, which is designed primarily as a delivery (and, conversely, a waste-removal) system (Reynolds et al., 2005a,c; Borowicz et al., 2007). In contrast, the microvascular architecture of the fetal placenta, which is highly branched and composed primarily of abundant small capillaries, is designed as a high velocity, rapid transport system (Reynolds et al., 2005c; Borowicz et al., 2007).

The suggested flow and transport differences between the maternal and fetal placental circulations agree with various functional observations. For example, umbilical blood flow increases at 2- to 3-times the relative rate (proportional or percentage increase per day) as that of uterine blood flow during the last twothirds of gestation (Reynolds and Redmer 1995; Reynolds et al., 2005a,b, 2006). Moreover, because of increased branching and thus larger numbers of capillaries per unit of tissue (Fig. 5), the surface area available for exchange is greater in fetal cotyledonary villi compared with maternal caruncles during the last third of pregnancy (Reynolds et al., 2005a,b). Additionally, the thickness of the barrier between the fetal and maternal capillaries also may be reduced throughout gestation (Faber and Thornburg, 1983; Longo 1987). Taken together, these observations help to explain why in normal pregnancies the proportion of the nutrients and oxygen taken up by the gravid uterus that is transported to the fetus increases by 2- to 4 -fold from mid to late gestation (and, conversely, the proportion that is utilized by the placenta decreases by 2 - to $4-4$-fold), essentially keeping pace with the rate of fetal growth (Reynolds and Redmer, 1995; Reynolds et al., 2005c).

Thus, although the placental microvascular architecture is ideally suited for both nutrient delivery, on the maternal side, and nutrient uptake and transport, on the fetal side, this arrangement does not appear to be unique to sheep. For example, there are several striking similarities in placental function between the sheep and the cow, which is another placentomal, or cotyledonary, mammal (Reynolds and Redmer, 1995; Vonnahme et al., 2007). The capillary plexus that forms on the maternal portion of the placenta also has been observed in pigs early in pregnancy (Assheton 1906; King et al., 1982), although to our knowledge this has not been examined later in pregnancy. In primates, including humans, the chorioallantois is so invasive that a portion of the maternal endometrium is eroded, and the fetal villi are bathed in maternal blood (Ramsey, 1982); this arrangement thus represents the ultimate in a low-velocity, irrigation-flow system. It is interesting to note that this 'hemochorial' type of placenta (signifying that the chorion, or outer layer of the chorioallantois, is bathed in maternal blood) is widespread among mammals, being nonpregnant caruncle with a caruncle on day 30 and 50 gestation; Fig. 6). By the beginning of the last third of pregnancy 
present not only in the vast majority of primates but also in rodents, insectivores, and bats, which together comprise $95 \%$ of the more than 4,000 species of mammals (Ramsey, 1982; Nowak, 1991).

As summarized in Table 1, in sheep studied during late gestation, uterine or umbilical blood flows, or both, are reduced in every model of compromised pregnancy in which they have been evaluated. These models of compromised pregnancy include overfed adolescents, underfed adolescents and adults, as well as environmental heat-stress, hypoxic stress, and multiple fetuses. These observations agree with those in women, in which placental perfusion is reduced in pregnancies with growth restricted fetuses (Poston, 1997; Moore et al., 2004; Redmer et al., 2004; Huppertz and Peeters, 2005).

In these various models of compromised pregnancy, although placental vascular development also is decreased in some instances, it is increased in others (Table 1). Interestingly, in two of the models in which placental vascularity is increased (high dietary Se, or hypoxic stress), there was no effect on fetal size, suggesting an adaptive placental response that preserves the fetal nutrient supply. In the other model exhibiting increased placental vascularity (Romanov vs. Columbia genotype), the animals were subject to long-term genetic selection, resulting in increased litter size. This latter case resembles that of Meishan and Yorkshire pigs, in which the Meishans exhibit increased litter size and weight associated with increased placental vascularity and VEGF expression (Biensen et al., 1998; Wilson et al., 1998; Vonnahme and Ford, 2004).

\section{Regulation of placental angiogenesis}

As we mentioned, angiogenesis refers to the formation of new vascular beds, and is a critical process for normal tissue growth and development, including that of the placenta (Reynolds and Redmer, 1995, 2001; Reynolds et al., 1992, 2005a,b, 2006). Although numerous molecules have been implicated in the regulation of vascular growth, recent observations have led to the identification of the major factors regulating vascularization in the placenta and elsewhere (Yancopoulos et al., 2000; Koh et al., 2002; Charnock-Jones et al., 2004; Reynolds et al., 2005a; Borowicz et al., 2007). These angiogenic factors include the vascular endothelial growth factor (VEGF), fibroblast growth factor (FGF), and angiopoietin (ANGPT) protein families, as well

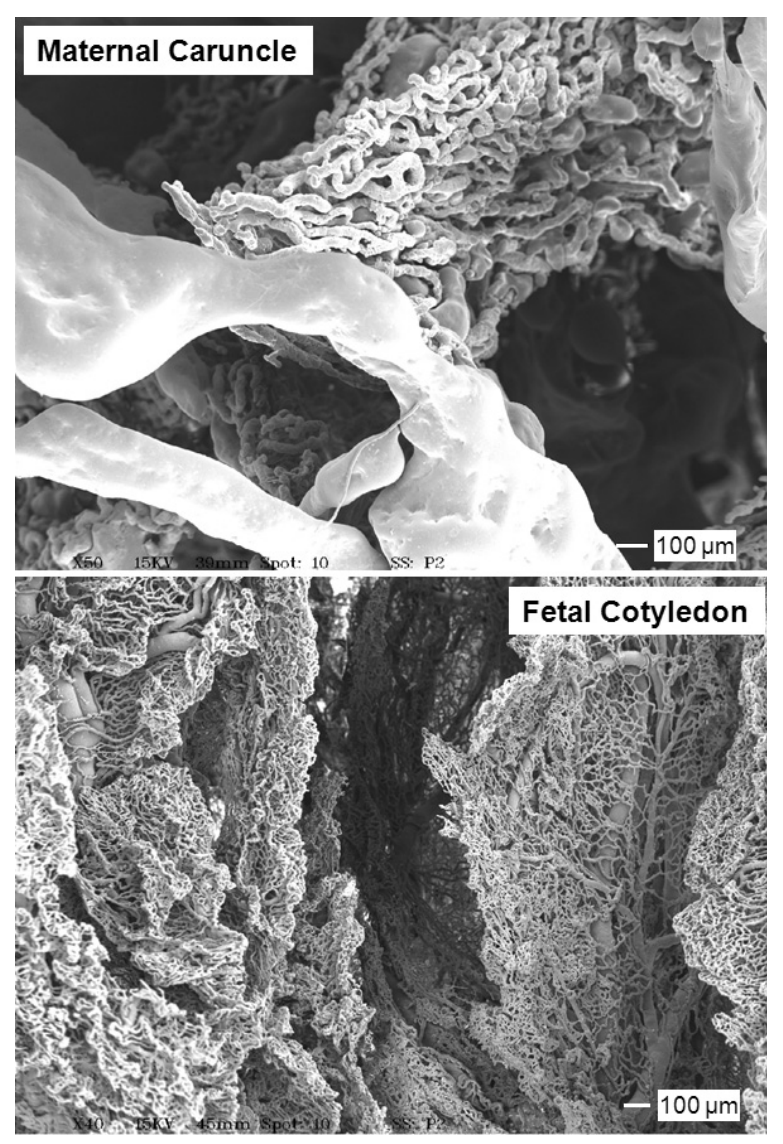

Fig. 7. Scanning electron photomicrographs of placental microvascular casts. Day 130 [0.9] of pregnancy; Hafez, Borowicz, Reynolds and Redmer, unpublished.

as their respective receptors. In terms of regulating uteroplacental angiogenic factor expression, estrogen seems to be a key player; in ovariectomized rats or ewes, endometrial VEGF, FGF, ANGPT1, and ANGPT2 mRNA are strongly upregulated within a few hours after estrogen treatment, in association with a dramatic increase in uterine vascularization and blood flow (Cullinan-Bove et al., 1993; Magness, 1998; Reynolds et al., 1998; Johnson et al., 2006), as is expression of the mRNA for endothelial nitric oxide synthase (eNOS, or NOS3), which produces nitric oxide (NO) and

TABLE 1

\section{CHANGES IN FETAL AND PLACENTAL WEIGHTS, UTERINE AND UMBILICAL BLOOD FLOWS, AND PLACENTAL VASCULARITY IN VARIOUS MODELS OF COMPROMISED PREGNANCY IN SHEEP ${ }^{1}$}

\begin{tabular}{|c|c|c|c|c|c|c|}
\hline Model & Day of gestation ${ }^{2}$ & Fetal weight & Placental weight & Uterine blood flow & Umbilical blood flow & Vascularity $^{3}$ \\
\hline Overfed Adolescent & $130-134$ & $\downarrow 20-28 \%$ & $\downarrow 45 \%$ & $\downarrow 36 \%$ & $\downarrow 37 \%$ & $\downarrow 31 \%$ (total capillary vol.) \\
\hline Underfed Adolescent & 130 & $\downarrow 17 \%$ & NSE & --- & ---- & $\downarrow 20 \%$ (cap. area density, CAR) \\
\hline Underfed Adult & $130-144$ & $\downarrow 12 \%$ & --- & $\downarrow 17-32 \%$ & NSE & $\downarrow 14 \%$ (cap. area density, CAR) \\
\hline Adolescent vs. Adult & 135 & $\downarrow 11 \%$ & $\downarrow 29 \%$ & ---- & --- & ---- \\
\hline Genotype & 130 & $\downarrow 43 \%$ & $\downarrow 47 \%$ & --- & --- & $\uparrow 36 \%$ \\
\hline Heat-stressed Adult & $133-135$ & $\downarrow 42 \%$ & $\downarrow 51 \%$ & $\downarrow 26 \%$ & $\downarrow 60 \%$ & --- \\
\hline Multiple Pregnancy & 140 & $\downarrow 30 \%$ & $\downarrow 37 \%$ & $\downarrow 23 \%$ & --- & $\downarrow 30 \%$ (total cap. vol., COT) \\
\hline High Dietary Se & 135 & NSE & $\downarrow 24 \%$ & ---- & --- & $\uparrow 20 \%$ (cap number density, COT) \\
\hline Hypoxic (Hypobaric) Stress & 140 & NSE & ---- & $\downarrow 35 \%^{\Delta}$ & --- & $\uparrow($ cap. area density, CAR \& COT) \\
\hline
\end{tabular}

${ }^{1}$ Table adapted from Reynolds et al. (2006). ${ }^{2}$ Length of gestation = approximately 145 days. ${ }^{3}$ cap. = capillary; CAR = caruncle (maternal placenta); COT = cotyledon (fetal placenta/villus). 
TABLE 2

STANDARD PARTIAL REGRESSION COEFFICIENTS 1 ILLUSTRATING THE RELATIONSHIPS OF VARIOUS ANGIOGENIC FACTOR MRNA (INDEPENDENT VARIABLES) WITH MEASURES OF CARUNCULAR (MATERNAL PLACENTAL) VASCULARITY (DEPENDENT VARIABLES) OF SHEEP THROUGHOUT PREGNANCY2

\begin{tabular}{lcccc} 
Angiogenic & \multicolumn{4}{c}{ Measure of vascularity } \\
factor
\end{tabular}

${ }^{1}$ This procedure calculates standard partial regression coefficients, also termed $\beta$, which provide a measure of the relative contribution of the various independent variables to each dependent variable (Wright, 1934). The data for the regressions were taken from Borowicz et al. (2007); and the overall $\mathrm{R}^{2}=0.92,0.52,0.80$, and 0.76 for $\mathrm{CAD}, \mathrm{CND}, \mathrm{CSD}$, and $\mathrm{APC}$, respectively.

${ }^{2}$ Days of pregnancy were days $50,70,90,110,130$, and 140 ( $n=5$ ewes per day, except for day 90 , for which $\mathrm{n}=2$; Borowicz et al., 2007). Relative expression of angiogenic factor mRNA was by quantitative, real-time PCR, as described by Borowicz et al. (2007).

${ }^{3}$ VEGF = vascular endothelial growth factor; VEGFR1 = VEGF receptor-1 (FLT1); VEGFR2 = VEGF receptor-2 (KDR); FGF = fibroblast growth factor-2 (basic FGF); NOS3 = endothelial nitric oxide synthase; GUCY1B3 = soluble guanylate cyclase (NO receptor); ANGPT1 = angiopoietin1; ANGPT2 = angiopoietin-2; TIE2 = angiopoietin receptor; and HIF1 A = hypoxia-inducible factor1alpha.

${ }^{4} \mathrm{CAD}=$ capillary area density, $\mathrm{CND}=$ capillary number density, $\mathrm{CSD}=$ capillary surface density, and APC $=$ area per capillary (Borowicz et al., 2007).

${ }^{5}$ Standard partial regression coeffiencent $(\beta)$ with $P$-value in parentheses (significant $\beta$ are shown in bold).

${ }^{6} \mathrm{NS}=$ not significant $(\mathrm{P}>0.05)$.

thus is an important regulator of both angiogenesis and vasodilation (Rosenfeld etal., 1996; Magness, 1998; Vagnoni et al., 1998; Reynolds and Redmer, 2001; Redmer et al., 2005; Borowicz et al., 2007).

To evaluate the relationships among placental angiogenesis and expression of angiogenic factors in the sheep placenta, we recently determined the mRNA expression of a suite of placental angiogenic and vasoactive factors and also measured placental angiogenesis in the same ewes at 10- to 20-day intervals throughout the last two-thirds of gestation (Borowicz et al., 2007). To determine the relative contribution of these various factors to placental vascular development (that is, capillary area density, capillary number density, capillary surface density, and area per capillary), we have utilized a multiple regression procedure similar to Wright's (1934) method of 'path coefficient analysis.' This procedure calculates standard partial regression coefficients, which provide a measure of the relative contribution of the various independent variables to each dependent variable. As shown in Table 2, application of this methodology has provided some intriguing results. For example, although VEGF, NOS3, and ANGPT2 mRNA levels show a strong positive relationship, mRNA of several of the factors (for example, FGF, ANGPT1, and TIE2) show a strong negative relationship to capillary area density of the maternal placental (caruncular) tissues. Similarly, for capillary surface density, NOS3 mRNA shows a strong positive relationship, whereas that of HIF1A exhibits a strong negative relationship (Table 2). For area per capillary (capillary size), both VEGF and ANGPT2 mRNA show a strong positive relationship (Table 2). Surprisingly, none of the angiogenic or vasoactive factors evaluated showed a positive relationship to any of the measures of vascularity in the fetal placental (cotyledonary) tissues (Table 3). It seems obvious that much more work of this type needs to be done, and especially for more stages of pregnancy as well as in compromised pregnancies, to more fully understand the relationship between expression of angiogenic factors and the placental microvascular architecture.

\section{'Rescue' of placental angiogenesis and blood flow in compromised pregnancies}

Fetal growth restriction, resulting in low birth weight, occurs in 7 to $8 \%$ of human pregnancies in the United States, and is associated with increased perinatal mortality and morbidity (NLM, 2002a,b; NVSR, 2004). Because of the importance of placental blood flow to placental function, and the recognition that placental size, uteroplacental blood flows and angiogenesis, and expression of angiogenic and vasoactive factors are reduced or altered in compromised pregnancies, it has been suggested that therapeutic agents that target placental blood flow and vascular development could be used to ameliorate fetal growth restriction (Godfrey, 2002; Ahmad and Ahmed, 2005; Wu et al., 2004; Wareing et al., 2005; Reynolds et al., 2006).

Altered placental growth and vascular development has been associated with altered expression of the genes for the major angiogenic factors and their receptors (Redmer et al., 2005; Reynolds et al., 2005a,b, 2006; Luther et al., 2007; Vonnahme et al., 2007, 2008). In addition, placental explants from preeclamptic human pregnancies exhibit increased production and release of soluble VEGF receptor-1, which binds to and thereby inhibits the activity of VEGF ligands (Ahmad and Ahmed, 2005). Thus, placental angiogenic and vasoactive factors might serve as therapeutic targets in compromised pregnancies in humans (Godfrey, 2002; Ahmad and Ahmed, 2005; Reynolds et al., 2005a,b, 2006).

Nitric oxide is an important regulator of blood flow to the uterus in the nonpregnant state and also during pregnancy (Magness, 1998). Expression of both eNOS and GUCY1B3 (also known as soluble guanylate cyclase), which serves as the receptor for NO and thus mediates its effects in vascular smooth muscle, are elevated in uterine arteries during pregnancy (Itoh et al., 1998; Vagnoni et al., 1998; Zheng et al., 2000; Magness et al., 2001; Joyce et al., 2002). In addition, basal production of NO contributes to low fetoplacental vascular resistance during pregnancy (Sladek et al., 1997). Circulating NO and its metabolites are elevated in pregnancies with multiple compared with single fetuses (Vonnahme et al., 2005). Placental expression of eNOS is reduced in some models of compromised pregnancy, including various conditions associated with intrauterine growth restriction in humans (Bird et 
al., 2003; Maul et al., 2003; Wu et al., 2004; Redmer et al., 2005). Moreover, NO, produced by endothelial cells, and VEGF, produced primarily by vascular smooth muscle and capillary pericytes, may interact by stimulating each other's expression (Ahmed and Perkins, 2000; Reynolds and Redmer, 2001). Thus, impaired placental syntheses of NO may provide a unified explanation for fetal growth retardation in both underfed and overfed sheep models of fetal growth restriction (Wu et al., 2004).

Thus, perhaps some of the best candidates for therapeutic agents to rescue placental blood flow and angiogenesis are the phosphodiesterase 5 (PDE5A)-specific inhibitors, which include sildenafil, tadalafil, and vardenafil (marketed under the trade names Viagra, Cialis, and Levitra, respectively). These pharmacological agents enhance the vasodilatory action of NO by inhibiting the breakdown of cGMP, the second messenger for NO, thus causing sustained relaxation of vascular smooth muscle (Michel, 2006). Sildenafil enhanced both basal and estrogen-induced increases in uterine blood flow in ovariectomized ewes (Zoma et

\section{TABLE 3}

STANDARD PARTIAL REGRESSION COEFFICIENTS ${ }^{1}$ ILLUSTRATING THE RELATIONSHIPS OF VARIOUS ANGIOGENIC FACTOR MRNA (INDEPENDENT VARIABLES) WITH MEASURES OF COTYLEDONARY (FETAL PLACENTAL) VASCULARITY (DEPENDENT VARIABLES) OF SHEEP THROUGHOUT PREGNANCY ${ }^{2}$

\begin{tabular}{|c|c|c|c|c|}
\hline \multirow{2}{*}{$\begin{array}{l}\text { Angiogenic } \\
\text { factor }^{3}\end{array}$} & \multicolumn{4}{|c|}{ Measure of vascularity ${ }^{4}$} \\
\hline & CAD & CND & CSD & APC \\
\hline VEGF & $\begin{array}{c}-0.067^{5} \\
\text { NS }^{6}\end{array}$ & $\begin{array}{c}0.200 \\
\text { NS }\end{array}$ & $\begin{array}{l}0.086 \\
\text { NS }\end{array}$ & $\begin{array}{c}-0.128 \\
\text { NS }\end{array}$ \\
\hline VEGFR1 & $\begin{array}{c}-0.231 \\
\text { NS }\end{array}$ & $\begin{array}{c}-0.086 \\
\text { NS }\end{array}$ & $\begin{array}{c}-0.134 \\
\text { NS }\end{array}$ & $\begin{array}{c}-0.011 \\
\text { NS }\end{array}$ \\
\hline VEGFR2 & $\begin{array}{c}-0.175 \\
\text { NS }\end{array}$ & $\begin{array}{c}-0.033 \\
\text { NS }\end{array}$ & $\begin{array}{c}-0.126 \\
\text { NS }\end{array}$ & $\begin{array}{c}0.006 \\
\text { NS }\end{array}$ \\
\hline FGF & $\begin{array}{c}-0.239 \\
\text { NS }\end{array}$ & $\begin{array}{l}-0.229 \\
(0.026)\end{array}$ & $\begin{array}{c}-0.203 \\
\text { NS }\end{array}$ & $\begin{array}{c}0.122 \\
\text { NS }\end{array}$ \\
\hline NOS3 & $\begin{array}{c}0.204 \\
\text { NS }\end{array}$ & $\begin{array}{c}0.051 \\
\text { NS }\end{array}$ & $\begin{array}{c}0.083 \\
\text { NS }\end{array}$ & $\begin{array}{c}0.304 \\
\text { NS }\end{array}$ \\
\hline GUCY1B3 & $\begin{array}{c}0.043 \\
\text { NS }\end{array}$ & $\begin{array}{c}-0.009 \\
\text { NS }\end{array}$ & $\begin{array}{c}-0.005 \\
\text { NS }\end{array}$ & $\begin{array}{c}-0.082 \\
\text { NS }\end{array}$ \\
\hline ANGPT1 & $\begin{array}{c}-0.066 \\
\text { NS }\end{array}$ & $\begin{array}{l}-0.271 \\
(0.010)\end{array}$ & $\begin{array}{c}-0.173 \\
\text { NS }\end{array}$ & $\begin{array}{c}0.208 \\
\text { NS }\end{array}$ \\
\hline ANGPT2 & $\begin{array}{l}0.509 \\
\text { NS }\end{array}$ & $\begin{array}{c}0.088 \\
\text { NS }\end{array}$ & $\begin{array}{c}0.348 \\
\text { NS }\end{array}$ & $\begin{array}{c}0.090 \\
\text { NS }\end{array}$ \\
\hline TIE2 & $\begin{array}{l}0.206 \\
\text { NS }\end{array}$ & $\begin{array}{c}0.108 \\
\text { NS }\end{array}$ & $\begin{array}{c}0.182 \\
\text { NS }\end{array}$ & $\begin{array}{c}-0.117 \\
\text { NS }\end{array}$ \\
\hline HIF1A & $\begin{array}{c}-0.228 \\
\text { NS }\end{array}$ & $\begin{array}{c}-0.130 \\
\text { NS }\end{array}$ & $\begin{array}{c}-0.190 \\
\text { NS }\end{array}$ & $\begin{array}{c}-0.143 \\
\text { NS }\end{array}$ \\
\hline
\end{tabular}

${ }^{1}$ This procedure calculates standard partial regression coefficients, also termed $\beta$, which provide a measure of the relative contribution of the various independent variables to each dependent variable (Wright, 1934). The data for the regressions were taken from Borowicz et al. (2007); and the overall $R^{2}=0.85,0.96,0.91$, and 0.88 for CAD, CND, CSD, and APC, respectively.

${ }^{2}$ Days of pregnancy were days $50,70,90,110,130$, and $140(n=5$ ewes per day, except for day 90 , for which $\mathrm{n}=2$; Borowicz et al., 2007). Relative expression of angiogenic factor mRNA was by quantitative, real-time PCR, as described by Borowicz et al. (2007).

${ }^{3}$ VEGF = vascular endothelial growth factor; VEGFR1 = VEGF receptor-1 (FLT1); VEGFR2 = VEGF receptor-2 (KDR); FGF = fibroblast growth factor-2 (basic FGF); NOS3 = endothelial nitric oxide synthase; GUCY1B3 = soluble guanylate cyclase (NO receptor); ANGPT1 = angiopoietin1; ANGPT2 = angiopoietin-2; TIE2 = angiopoietin receptor; and HIF1 A = hypoxia-inducible factor1alpha.

${ }^{4} \mathrm{CAD}=$ capillary area density, CND = capillary number density, CSD = capillary surface density, and APC = area per capillary (Borowicz et al., 2007).

${ }^{5}$ Standard partial regression coeffiencent $(\beta)$ with $P$-value in parentheses (significant $\beta$ are shown in bold).

${ }^{6} \mathrm{NS}=$ not significant $(\mathrm{P}>0.05)$.

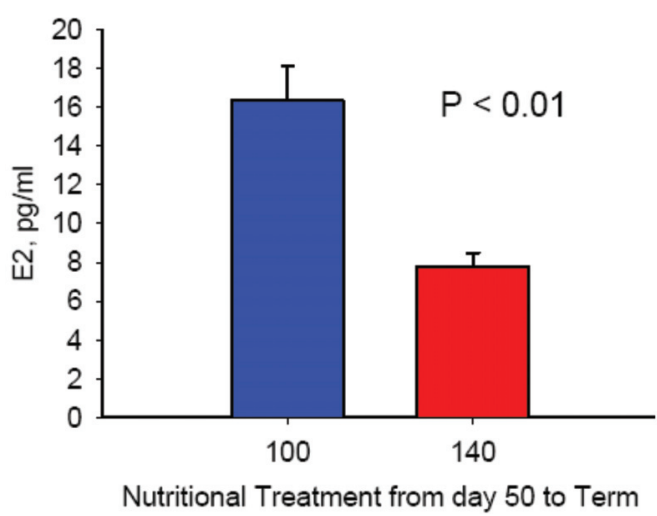

Fig. 8. Estradiol concentrations in dams fed to 100 or $140 \%$ of dietary intake requirements from day $\mathbf{5 0}$ after mating until term. Vonnahme, Redmer, Reynolds and Caton, unpublished data.

al., 2004). Sildenafil also has been shown to stimulate vasorelaxation of myometrial arteries from women whose fetuses were growth restricted (Wareing et al., 2005). Thus, PDE5 inhibitors do indeed seem a likely therapeutic agent to increase uteroplacental perfusion, and perhaps also placental angiogenesis, in compromised pregnancies, and this suggestion is supported by preliminary studies (Reynolds et al., 2006).

In addition to alterations in PDE5A activity, nutriceutical approaches may also be used to manipulate the NO system. Citrulline is a precursor of arginine, which is the substrate for NO synthesis via any of the various NOS (Flynn et al., 2002). Fetal growth retardation induced by maternal undernutrition from day 28 to day 78 of gestation in sheep was associated with a decrease in arginine and citrulline in maternal plasma, fetal plasma, and allantoic fluid by 23 to $30 \%$ at Day 78 of gestation (Kwon et al., 2004). Further, concentrations of biopterin (an indicator of de novosynthesis of tetrahydrobiopterin $\left[\mathrm{BH}_{4}\right]$, which is an essential cofactor for NOS) in fetal plasma, and amniotic and allantoic fluids, were reduced by 32 to $36 \%$ in underfed ewes (G. Wu, unpublished results, as referenced in Reynolds et al., 2006), indicating reduced availability of $\mathrm{BH}_{4}$ for $\mathrm{NO}$ production in the conceptus. These changes could impair placental and fetal NO synthesis, thereby resulting in reduced placental blood flow, in underfed ewes (Bell and Ehhardt 2002; Kwon et al., 2004).

In view of the critical roles of the arginine-dependent metabolic pathways, intravenous or oral administration of arginine may provide a therapeutic strategy to enhance uterine and placental blood flow in compromised pregnancies, thereby improving fetal growth. Indeed, Xiao and Li (2005) recently reported that daily intravenous infusion of arginine for 7 days during late gestation (week 33), to women with unknown causes of fetal intrauterine growth restriction, resulted in a $6.4 \%$ increase in birth weight at term. Similarly, dietary supplementation of arginine throughout gestation resulted in a $24 \%$ increase in live litter weight in pigs (Mateo et al., 2007), and supplementation of arginine to lactating sows increased piglet body weight gain by $11 \%$ through day 21 postpartum (Mateo et al., 2008).

As mentioned above, estrogen appears to be the primary regulator of uteroplacental angiogenesis via its strong upregulation of angiogenic and vasoactive factors (Rosenfeld et al.,

1996; Magness, 1998; Vagnoni et al., 1998; Cullinan-Bove et 
al., 1993; Magness, 1998; Reynolds et al., 1998; Johnson et al., 2006). Recently, in one of our models of compromised pregnancy; namely, the overfed, adolescent ewe, we have found dramatically reduced maternal systemic estradiol levels during the last half of gestation (Wallace et al., 2008; Vonnahme et al., unpublished, Fig. 8). Whether the reduced maternal estradiol levels are due to increased metabolism or reduced placental production of estrogens remains to be determined. Nevertheless, reduced circulating estradiol is a likely culprit in the reduced placental blood flow and angiogenesis observed in this model (Table 1), leaving open the possibility of estrogen replacement therapy to rescue placental function and thus fetal growth and development in this type of compromised pregnancy (Wallace et al., 2008).

\section{Summary and challenges}

Nearly 15 years ago, we reviewed the current state of knowledge concerning uteroplacental vascular development, its contribution to placental function, and, ultimately, its importance to fetal and neonatal growth and development. In the intervening period, we have learned much more about the critical role of placental vascular development in placental function in both normal pregnancy as well as numerous models of compromised pregnancy, including those in which fetal or placental growth, or both, are reduced due to abnormal maternal dietary intake, increased numbers of fetuses, maternal or fetal genotype, maternal age, or maternal environmental stress. We also have learned much about the factors that regulate placental vascular growth, or angiogenesis. Based on these observations, we suggest several potential therapeutic approaches to 'rescuing' placental vascular development, and thus fetal and placental growth and development.

Although we have learned much in a relatively short time, we obviously have much more to do. For example, we need a much better understanding of when and where and how changes in angiogenic factor expression and the process of angiogenesis itself occur in various compromised pregnancies, and the effects of various therapeutic agents not only on fetal and placental growth and development but also on postnatal outcomes. It seems equally obvious that animal models of compromised pregnancy will be critical to solving these problems, which have large socioeconomic consequences.

\section{Acknowledgements}

We wish to acknowledge the support of the North Dakota State Board of Agricultural Research and Education; the U.S. Department of Agriculture, Competitive Grants Program; the U.S. National Institutes of Health; and the U.S. National Science Foundation; we also wish to acknowledge the contributions of our students and colleagues to this work, including Drs. Daniel Arnold, Leonardo Della Salda, Stephen Ford, Mary Lynn Johnson, Pasqualino Loi, Chiara Palmieri, Grazyna Ptak, Abraham Scheaffer, Thomas Spencer, Jacqueline Wallace, Guoyao Wu, and Jing Zheng.

\section{References}

ADAIR TH, GAY WJ, MONTANI J-P (1990). Growth regulation of the vascular system: evidence for a metabolic hypothesis. Am J Physio/259: R393-R404.

AHMAD S, AHMED A (2005). Antiangiogenic effect of soluble vascular endothelial growth factor receptor-1 in placental angiogenesis. Endothelium 12: 89-95.

AHMED A, PERKINS J (2000). Angiogenesis and intrauterine growth restriction.
Baillieres Best Pract Res Clin Obstet Gynaecol14: 981-98.

ANTHONY RV, SCHEAFFER AN, WRIGHT CD \& REGNAULT TR (2003). Ruminant models of prenatal growth restriction. Reproduction Suppl. 61: 183-194.

ASSHETON R (1906). The morphology of the ungulate placenta, particularly the development of that organ in sheep, and notes upon the placenta of the elephant and hyrax. Phil Trans Royal Soc (London), Ser B 198: 143-220.

BASSINGTHWAIGHTE JB, GORESKY CA. (1984). Modeling in the analysis of solute and water exchange in the microvasculature. In Handbook of Physiology, sec. 2, vol. IV, part 1 (Eds. E. Renkin and C.C.Michel. American Physiological Society, Bethesda, MD, pp. 549-626.

BELL AW, EHRHARDT RA (2002). Regulation of placental nutrient transport and implications for fetal growth. Nutr Res Rev 15: 211-230.

BELL AW, HAY WW JR, EHRHARDT RA (1999). Placental transport of nutrients and its implications for fetal growth. J Reprod FertilSuppl 54: 401-10.

BIENSEN NJ, WILSON ME, FORD SP (1998). The impact of either a Meishan or Yorkshire uterus on Meishan or Yorkshire fetal and placental development to days 70, 90, and 110 of gestation. J Anim Sci76: 2169-76.

BIRD IM, ZHANG L, MAGNESS RR (2003). Possible mechanisms underlying pregnancy-induced changes in uterine artery endothelial function. Am J Physiol Regul Integr Comp Physio/284: R245-58.

BOROWICZ PP, ARNOLD DR, JOHNSON ML, GRAZUL-BILSKA AT, REDMER DA, REYNOLDS LP (2007). Placental growth throughout the last two-thirds of pregnancy in sheep: Vascular development and angiogenic factor expression. Biol Reprod. 76: 259-267.

CHARNOCK-JONES DS, KAUFMANN P, MAYHEW TM (2004). Aspects of human fetoplacental vasculogenesis and angiogenesis. I. Molecular regulation. P/a centa 25: 103-113.

CULLINAN-BOVE K, KOOS RD. (1993) Vascular endothelial growth factor/vascular permeability factor expression in the rat uterus: Rapid stimulation by estrogen correlates with estrogen-induced increases in uterine capillary permeability and growth. Endocrinology 133: 829-837.

FABER JJ, THORNBURG KL (1983). Placental Physiology. Structure and Function of Fetomaternal Exchange. Raven Press, New York.

FERRAZZI E, RIGANO S, BOZZO M, BELLOTTI M, GIOVANNINI N, GALAN H, BATTAGLIA FC (2000). Umbilical vein blood flow in growth-restricted fetuses. Ultrasound Obstet Gyneco/16: 432-438.

FLYNN NE, MEININGER CJ, HAYNES TE, WU G (2002). The metabolic basis of arginine nutrition and pharmacotherapy. Biomed Pharmacother 56: 427-38.

GODFREY KM (2002). The role of the placenta in fetal programming-a review. Placenta 23 Suppl A: S20-7.

HAFEZ SA, CACECI T, FREEMAN LE, PANTER KE. (2007) Angiogenesis in the caprine caruncles in nonpregnant and pregnant normal and swainsoninetreated does. Anat Rec 290: 761-769.

HUDLICKA O. (1984). Development of microcirculation: Capillary growth and adaptation. In: Handbook of Physiology, sec. 2, vol. IV, part 1 (Eds. E. Renkin and C.C.Michel. American Physiological Society, Bethesda, MD, pp. 165-216.

HUPPERTZ B, PEETERS LL (2005). Vascular biology in implantation and placentation. Angiogenesis 8: 157-67.

HUTCHINS GM, MINER MM, BOITNOTT JK. (1976) Vessel caliber and branchangle of human coronary artery branch-points. Circ Res 38: 572-576.

ITOH H, BIRD IM, NAKAO K, MAGNESS RR (1998). Pregnancy increases soluble and particulate guanylate cyclases and decreases the clearance receptor of natriuretic peptides in ovine uterine, but not systemic, arteries. Endocrinology 139: 3329-3341.

JABLONKA-SHARIFF A., GRAZUL-BILSKA AT, REDMER DA, REYNOLDS LP (1993). Growth and cellular proliferation of ovine corpora lutea throughout the estrous cycle. Endocrinology 133: 1871-1879.

JABLONKA-SHARIFF A, REYNOLDS LP, REDMER DA (1996). Effects of gonadotropin treatment and withdrawal on follicular growth, cell proliferation, and atresia in ewes. Biol Reprod55: 693-702.

JOHNSON ML, GRAZUL-BILSKA AT, REDMER DA, REYNOLDS LP (2006). Effects of estradiol-17 $\beta$ on expression of mRNA for seven angiogenic factors and their receptors in the endometrium of ovariectomized (OVX) ewes. Endocrine 30: 333-342.

JOYCE JM, PHERNETTON TM, SHAW CE, MODRICK ML, MAGNESS RR (2002). 
Endothelial vasodilator production by uterine and systemic arteries. IX. eNOS gradients in cycling and pregnant ewes. Am J Physiol Heart Circ Physio/282: H342-348.

KAUFMANN P, MAYHEW TM, CHARNOCK-JONES DS (2004). Aspects of human fetoplacental vasculogenesis and angiogenesis. II. Changes during normal pregnancy. Placenta 25: 114-126.

KING GJ, ATKINSON BA, ROBERTSON HA (1982). Implantation and early placentation in domestic ungulates. Reprod FertilSuppl 31: 17-30.

KOH GY, KIM I, KWAK HJ, YUN MJ, LEEM JC (2002). Biomedical significance of endothelial cell specific growth factor, angiopoietin. Exp Molec Med34: 1-11.

KONJE JC, HOWARTH ES, KAUFMANN P, TAYLOR DJ (2003). Longitudinal quantification of uterine artery blood volume flow changes during gestation in pregnancies complicated by intrauterine growth restriction. BritJ Obstet Gynecol 110: 301-305.

KWON H, FORD SP, BAZER FW, SPENCER TE, NATHANIELSZ PW, NIJLAND MJ, HESS BW, WU G (2004). Maternal nutrient restriction reduces concentrations of amino acids and polyamines in ovine maternal and fetal plasma and fetal fluids. Biol Reprod 71: 901-908.

LONGO LD (1972). Disorders of placental transfer. In: Pathophysiology of Gestation, Vol. II (Eds. N.S. Assali and S.R. Brinkman III). Academic Press, New York, pp. 1-76.

LONGO LD (1987). Respiratory gas exchange in the placenta. In: Handbook of Physiology, sec 3, vol IV (Eds. A.P. Fishman, L.E. Farhi and S.M. Tenney). American Physiological Society, Bethesda, MD, pp. 351-401.

LONGO LD and REYNOLDS LP (2010). Some historical aspects of understanding placental development, structure, and function. Int. J. Dev. Biol. 54: 237-255. (doi: $10.1387 / \mathrm{ijdb} .082774 \mathrm{II})$

LUTHER J, AITKEN R, MILNE J, MATSUZAKI M, REYNOLDS L, REDMER D, WALLACE J (2007). Maternal and fetal growth, body composition, endocrinology, and metabolic status in undernourished adolescent sheep. Bio/Reprod 77 : 343-350.

MAGNESS RR (1998). Maternal cardiovascular and other physiological responses to the endocrinology of pregnancy. In: The Endocrinology of Pregnancy (Ed. F.W. Bazer). Humana Press, Totowa, NJ, pp. 507-539.

MAGNESS RR, SULLIVAN JA, LI Y, PHERNETTON TM, BIRD IM (2001). Endothelial vasodilator production by uterine and systemic arteries. VI. Ovarian and pregnancy effects on eNOS and NO(x). Am J Physiol Heart Circ Physio/280: H1692-698.

MARCONI AM, PAOLINI C, BUSCAGLIA M, ZERBE G, BATTAGLIA FC, PARDI G (1996). The impact of gestation age and foetal growth upon the maternal-foetal glucose concentration difference. Obstet Gyneco/87: 937-942.

MATEO RD, WU G, BAZER FW, PARK JC, SHINZATO I, KIM SW (2007). Dietary L-arginine supplementation enhances the reproductive performance of gilts. $J$ Nutr 137: 652-656.

MATEO RD, WU G, MOON HK, CARROLL JA, KIM SW (2008). Effects of dietary arginine supplementation during gestation and lactation on the performance of lactating primiparous sows and nursing piglets. J Anim Sci 86: 827-835.

MAUL H, LONGO M, SAADE GR, GARFIELD RE (2003). Nitric oxide and its role during pregnancy: from ovulation to delivery. Curr Pharm Des 9: 359-80.

MAYHEW TM, CHARNOCK-JONES DS, KAUFMANN P (2004). Aspects of human fetoplacental vasculogenesis and angiogenesis. III. Changes in complicated pregnancies. Placenta 25: 127-139.

MESCHIA G (1983). Circulation to female reproductive organs. In: Handbook of Physiology, sec 2, vol III, part 1 (Eds. J.T. Shepherd and F.M. Abboud). American Physiological Society, Bethesda, MD, pp. 241-269.

METCALFE J, STOCK MK, BARRON DH (1988). Maternal physiology during gestation. In: The Physiology of Reproduction (Eds. E. Knobil, J. Neill, J.J. Ewing, et al.). Raven Press, New York, pp 2145-2176.

MICHEL T (2006). Treatment of myocardial ischemia. In: Goodman \& Gilman's The Pharmacological Basis of Therapeutics, $11^{\text {th }}$ edition (Eds. L.L. Brunton, J.S. Lazo and K.L. Parker. McGraw-Hill, New York, pp. 823-44.

MOORE LG, SHRIVER M, BEMIS L, HICKLER B, WILSON M, BRUTSAERT T, PARRA E, VARGAS E (2004). Maternal adaptation to high-altitude pregnancy: An experiment of nature - A review. Placenta 25 (Suppl. A) [Trophoblast Research 18]: S60-S71.
MOSSMAN HW (1987). Vertebrate Fetal Membranes. Rutgers University Press, New Brunswick, NJ.

MURRAY C.D. (1926) The physiological principle of minimum work. I. The vascular system and the cost of blood volume. Proc. Natl. Acad. Sci. USA 12: 207-214.

NLM (2002a). Adolescent Pregnancy. National Library of Medicine, MEDLINEplus. (http://www.nlm.nih.gov/medlineplus/ency/article/001516.htm\#prognosis, last accessed 18 September 2009)

NLM (2002b). Intrauterine Growth Restriction. National Library of Medicine, MEDLINEplus. (http://www.nlm.nih.gov/medlineplus/ency/article/001500.htm, last accessed 18 September 2009).

NORTH RA, FERRIER C, LONG D, TOWNEND K \& KINCAID-SMITH P (1994). Uterine artery Doppler flow velocity waveforms in the second trimester for the prediction of preeclampsia and fetal growth retardation. Obstet Gyneco/ 83: 378-386.

NOWAK RM (1991). Walker's Mammals of the World, $5^{\text {th }}$ Edition. The Johns Hopkins University Press, Baltimore.

NVSR. 2004. National Vital Statistics Reports, Vol. 53 No. 10 [DHHS Pub. No. (PHS) PHS) 2005-1120 '12PRS 04-0576 (11/2004)] (http://www.cdc.gov/nchs/ data/nvsr/nvsr53/nvsr53_10.pdf).

PARDI G, CETIN I, MARCONI AM, LANFRANCHI A, BOZZETTI P, FERRAZZI E, BUSCAGLIA M, BATTAGLIA FC (1993). Diagnostic value of blood sampling in fetuses with growth retardation. New England J Med 328: 692-696.

PALMIERI C, LOI P, REYNOLDS LP, PTAK G, DELLA SALDA L (2007). Placental abnormalities in ovine somatic cell clones at term: A light and electron microscopic investigation. Placenta 28: 577-584.

POSTON L (1997). The control of blood flow to the placenta. Exp Physio/82: 377 87.

RAMSEY EM (1982). The Placenta, Human And Animal. Praeger, New York.

REDMER DA, DORAISWAMY V, BORTNEM BJ, FISHER K, JABLONKA-SHARIFF A, GRAZUL-BILSKA, AT, REYNOLDS LP (2001). Evidence for a role of capillary pericytes in vascular growth of the developing ovine corpus luteum. Biol Reprod 65: 879-889.

REDMER DA, WALLACE JM, REYNOLDS LP (2004). Effects of nutrient intake during pregnancy on fetal and placental growth and vascular development. Domestic Anim Endocrino/27: 199-217.

REDMER DA, AITKEN RP, MILNE JS, REYNOLDS LP \& WALLACE JM (2005). Influence of maternal nutrition on messenger rna expression of placental angiogenic factors and their receptors at mid-gestation in adolescent sheep. Biol Reprod72: 1004-1009.

REYNOLDS LP, REDMER DA (1988). Secretion of angiogenic activity by placental tissues of cows at several stages of gestation. J Reprod Fertil 83: 497-502.

REYNOLDS LP, REDMER DA (1992). Growth and microvascular development of the uterus during early pregnancy in ewes. Biol Reprod 47: 698-708.

REYNOLDS LP, REDMER DA (1995). Uteroplacental vascular development and placental function. J Anim Sci73: 1839-1851.

REYNOLDS LP, REDMER DA (2001). Minireview: Angiogenesis in the placenta. Biol Reprod 64: 1033-1040.

REYNOLDS LP, FERRELL CL, NIENABER JA, FORD SP (1985). Effects of chronic environmental heat-stress on blood flow and nutrient uptake of the gravid bovine uterus and foetus. J Agric Sci, Cambr 104: 289-297.

REYNOLDS LP, FERRELL CL, ROBERTSON DA (1986) Metabolism of the gravid uterus, foetus and uteroplacenta at several stages of gestation in cows. J Agric Sci, Cambr 106: 437-444.

REYNOLDS LP, KILLILEA SD, REDMER DA (1992). Angiogenesis in the female reproductive system. FASEB J6: 886-892.

REYNOLDS LP, KIRSCH JD, KRAFT KC, REDMER DA (1998). Time-course of the uterine response to estradiol-17 $\beta$ in ovariectomized ewes:Expression of angiogenic factors. Biol Reprod 59: 613-620.

REYNOLDS.P, BOROWICZ PP, VONNAHME KA, JOHNSON ML, GRAZULBILSKA AT, REDMER DA, CATON JS (2005a). Placental angiogenesis in sheep models of compromised pregnancy. J Physio/565.1: 43-58

REYNOLDS LP, BOROWICZ PP, VONNAHME KA, JOHNSON ML, GRAZULBILSKA AT, WALLACE JM, CATON JS, REDMER DA (2005b). Animal models of placental angiogenesis. Placenta 26: 689-708. 
REYNOLDSLP, BIONDINIME, BOROWICZPP, GRAZUL-BILSKAAT, VONNAHME KA, CATON JS, REDMER DA (2005c). Functional significance of developmental changes in placental microvascular architecture: The sheep as a model. Endothelium 12: 11-19.

REYNOLDS LP, CATON JS, REDMER DA, GRAZUL-BILSKA AT, VONNAHME KA, BOROWICZ PP, LUTHER JS, WALLACE JM, WU G, SPENCER TE (2006). Topical Review: Evidence for altered placental blood flow and vascularity in compromised pregnancies. J Physio. 572: 51-58.

ROSENFELD CR, COX BE, ROY T, MAGNESS RR (1996). Nitric oxide contributes to estrogen-induced vasodilation of the ovine uterine circulation. J Clin Invest 98: 2158-2166.

SLADEK SM, MAGNESS RR, CONRAD KP (1997). Nitric oxide and pregnancy. Am $J$ Physio/272: R441-463.

TRUDINGER BJ, GILES WB, COOK CM (1985). Uteroplacental blood flow velocitytime waveforms in normal and complicated pregnancy. BritJObstet Gyneco/92: 39-45.

VAGNONI KE, SHAW CE, PHERNETTON TM, MEGLIN BM, BIRD IM, MAGNESS RR (1998). Endothelial vasodilator production by uterine and systemic arteries. III. Ovarian and estrogen effects on NO synthase. Am J Physio/275: H1845H1856.

VONNAHME KA, FORD SP (2004). Differential expression of the vascular endothelial growth factor-receptor system in the gravid uterus of yorkshire and Meishan pigs. Biol Reprod71: 163-169.

VONNAHME KA, WILSON ME, FORD SP (2001). Relationship between placental vascular endothelial growth factor expression and placental/endometrial vascularity in the pig. Biol Reprod64: 1821-1825.

VONNAHME KA, WILSON ME, FORD SP (2002). Conceptus competition for uterine space: Different strategies exhibited by the Meishan and Yorkshire pig. $J$ Anim Sci80: 1311-1316.

VONNAHME KA, WILSON ME, LIY, RUPNOW HL, PHERNETTON TM, FORD SP, MAGNESS RR (2005). Circulating levels of nitric oxide and vascular endothelial growth factor throughout ovine pregnancy. J Physio/565: 101-109.

VONNAHME KA, ZHU MJ, BOROWICZ PP, GEARY TW, HESS BW, REYNOLDS LP, CATON JS, MEANS WJ, FORD SP (2007). Effect of early gestational undernutrition on angiogenic factor expression and vascularity in the bovine placentome. J Anim Sci85, 2464-2472.

VONNAHME KA, EVONIUK J, JOHNSON ML, BOROWICZ PP, REDMER DA,
REYNOLDS LP, GRAZUL-BILSKA AT. Placental vascularity and growth factor expression in singleton, twin, and triplet pregnancies in the sheep. Endocrine 2008. 33: 53-61.

WALLACE JM, REGNAULT TR, LIMESAND SW, HAY WW JR, ANTHONY RV (2005). Investigating the causes of low birth weight in contrasting ovine paradigms. J Physio/565(Pt 1): 19-26.

WALLACE JM, MILNE JS, AITKEN RP, REDMER DA, REYNOLDS LP (2008). Putative role for oestrogen as the missing link between nutrition and fetoplacental growth restriction in overnourished adolescent sheep. Proc Physiol Soc 11: PC37, Cambridge Univ.

WAREING M, MYERS JE, O'HARA M, BAKER PN (2005). Sildenafil citrate (Viagra) enhances vasodilatation in fetal growth restriction. J Clin Endocrino/Metab90: 2550-5.

WEST GB, BROWN JH, ENQUIST BJ (1997). A general model for the origin of allometric scaling laws in biology. Science 276: 122-126.

WILSON ME, BIENSEN NJ, YOUNGS CR, FORD SP (1998). Development of Meishan and Yorkshire littermate conceptuses in either a Meishan or Yorkshire uterine environment to day 90 of gestation and to term. Bio/Reprod58: 905-910.

WOODING FBP, FLINT APF (1994). Placentation. In: Marshall's Physiology of Reproduction $4^{\text {th }}$ Edition (Ed. G.E. Lamming). Chapman \& Hall, London, pp. 233-460.

WRIGHT, S. 1934. The method of path coefficients. Ann Math Stat5: 161-216.

WU G, BAZER FW, CUDD TA, MEININGER CJ, SPENCER TE (2004). Maternal nutrition and fetal development. J Nutr 134: 2169-2172.

XIAO XM, LI LP (2005). L-arginine treatment for asymmetric fetal growth restriction. Int $J$ Gynecol Obstet 88: 15-18.

YANCOPOULOS GD, DAVIS S, GALE NW, RUDGE JS, WIEGAND SJ, HOLASH $J(2000)$. Vascular-specific growth factors and blood vessel formation. Nature 407: 242-248.

ZHENG J, LI Y, WEISS AR, BIRD IM, MAGNESS RR (2000). Expression of endothelial and inducible nitric oxide synthases and nitric oxide production in ovine placental and uterine tissues during late pregnancy. Placenta 21: 516524.

ZOMA WD, BAKER RS, CLARK KE (2004). Effects of combined use of sildenafil citrate (Viagra) and 17beta-estradiol on ovine coronary and uterine hemodynamics. Am J Obstet Gyneco/190: 1291-1297. 
Further Related Reading, published previously in the Int. J. Dev. Biol.

See our related Special Issue Placenta in honor of Allen C. Enders and edited by Joan S. Hunt and Kent L. Thornburg at: http://www.ijdb.ehu.es/web/contents.php?vol=54\&issue=1-2

See Special Issue Epigenetics \& Development edited by Saadi Khochbin and Stefan Nonchev at: http://www.ijdb.ehu.es/web/contents.php?vol=53\&issue=2-3

See Special Issue Pattern Formation edited by Michael K. Richardson and Cheng-Ming Chuong at:

http://www.ijdb.ehu.es/web/contents.php?vol=53\&issue=5-6

Some historical aspects of understanding placental development, structure and function

Lawrence D. Longo and Lawrence P. Reynolds

Int. J. Dev. Biol. (2010) 54: 237-255 (doi: 10.1387/ijdb.082774II).

Critical growth factors and signalling pathways controlling human trophoblast invasion Martin Knöfler

Int. J. Dev. Biol. (2010) 54: 269-280 (doi: 10.1387/ijdb.082769mk)

The influence of the intrauterine environment on human placental development Graham J. Burton, Eric Jauniaux and D. Stephen Charnock-Jones Int. J. Dev. Biol. (2010) 54: 303-312 (doi: 10.1387/ijdb.082764gb)

Developmental cell biology of human villous trophoblast: current research problems John D. Aplin

Int. J. Dev. Biol. (2010) 54: 323-329 (doi: 10.1387/ijdb.082759ja)

Estrogen regulation of placental angiogenesis and fetal ovarian development during primate pregnancy

Eugene D. Albrecht and Gerald J. Pepe

Int. J. Dev. Biol. (2010) 54: 397-408 (doi: 10.1387/ijdb.082758ea)

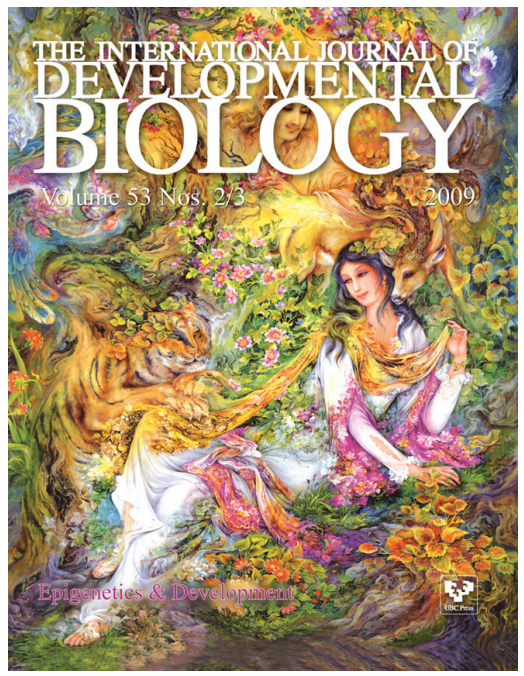

5 yr ISI Impact Factor $(2008)=3.271$
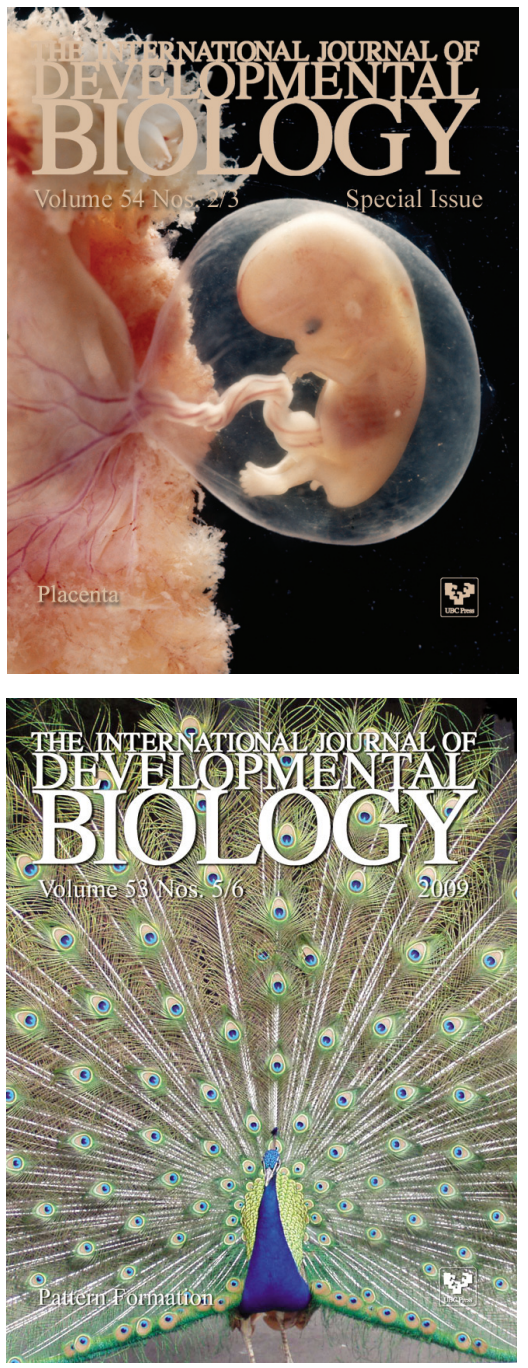